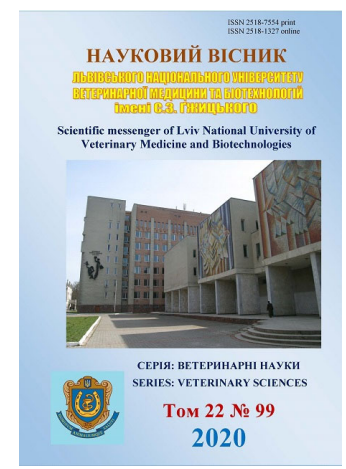

\author{
Науковий вісник Яьвівського національного університету \\ ветеринарної медицини та біотехнодогій імені С.3. Гжицького. \\ Серія: Ветеринарні науки \\ Scientific Messenger of Lviv National University \\ of Veterinary Medicine and Biotechnologies. \\ Series: Veterinary sciences
}

\title{
Research antianemic action of the iron (IV) clathrochelate complexes on the sickling piglets
}

\author{
V. B. Dukhnitskyi ${ }^{1}$, I. M. Derkach ${ }^{1}$, S. S. Derkach ${ }^{1}$, I. O. Fritsky ${ }^{2}$, M. O. Plutenko ${ }^{2}$, V. M. Lozovyi ${ }^{1}$, \\ V. V. Kostrub ${ }^{1}$, Y. V. Losa ${ }^{1}$ \\ ${ }^{I}$ National University of Life and Environmental Sciences of Ukraine, Kyiv, Ukraine \\ ${ }^{2}$ Taras Shevchenko National University of Kyiv, Kyiv, Ukraine
}

Article info

Received 10.09.2020 Received in revised form 12.10 .2020 Accepted 13.10.2020

National University of Life and Environmental Sciences of

Ukraine, Heroyiv Oborony Str., 15

Kyiv, 03041, Ukraine.

Tel.: +38-066-772-41-94

E-mail:irina1215@ukr.net

Taras Shevchenko National University of Kyiv,

Volodymyrska Str., 64

Kyiv, 01601, Ukraine

Tel $\cdot+38-097-060-82-98$

E-mail:plutenkom@gmail.com
Dukhnitskyi, V. B., Derkach, I. M., Derkach, S. S., Fritsky, I. O., Plutenko, M. O., Lozovyi, V. M., Kostrub, V. V., \& Losa, Y. V. (2020). Research antianemic action of the iron (IV) clathrochelate complexes on the sickling piglets. Scientific Messenger of Lviv National University of Veterinary Medicine and Biotechnologies. Series: Veterinary sciences, 22(99), 107-115. doi: $10.32718 /$ nvlvet 9917

A lot of antianemic drugs for animals are presented on the modern pharmaceutical market of veterinary medicine, but they have several drawbacks. So finding new drugs with goal to treat ill animals by anemia and to prevent the iron deficiency anemia is a pressing issue. We previously reported the results of preclinical studies of iron in rare high valence IV. This allowed us to determine, supplement, and generalize the data on clinical studies of the new drugs with the active substance iron (IV) clathrochelate. Therefore, the article presents the results of studies of its antianemic effect on sickling piglets. Experiments were carried out on piglets-analogues neonates, which were divided into three groups: control and two experimental groups. Piglets were kept with sows on suckling. For the purpose of prevention iron deficiency anemia the traditional solution of iron dextran was administered once intramuscularly to piglets of I control group. The aqueous solution of iron (IV) clathrochelate complexes was administered once intramuscularly to piglets of II experimental group. Iron (IV) clathrochelate complexes was dissolved in a solvent of rheopolyglucin and administered once intramuscularly to piglets of III experimental group. $1 \mathrm{~mL}$ of test solutions contained $100 \mathrm{mg}$ of active substance. The investigative material were the samples of blood and serum of piglets, their liver and spleen. The experiment lasted during a 30-day period since birth of piglets. According to the results of the experiments, iron (IV) clatrochelate complexes which was dissolved in a water for injection and rheopolyglucin had higher antianemic activity compared to the control. This is evidenced by the dynamics of probable changes in the number of erythrocytes, hemoglobin content and hematocrit, Iron content in serum and its mass fraction in the blood, liver and spleen of piglets. The effectiveness of the action of iron (IV) clatrochelate complexes is explained by the full supply of piglets with iron and its higher bioavailability.

Key words: iron deficiency anemia, clinical studies, iron (IV), piglets, morphological parameters, biochemical indicators.

\section{Дослідження протианемічної дії клатрохелату Феруму (IV) на поросятах}

\author{
В. Б. Духницький ${ }^{1}$, I. М. Деркач ${ }^{1}$, С. С. Деркач ${ }^{1}$, I. О. Фрицький ${ }^{2}$, М. О. Плутенко을 В. М. Лозовий ${ }^{1}$, \\ В. В. Коструб ${ }^{1}$, Ю. В. Лоза ${ }^{1}$
}

${ }^{1}$ Національний університет біоресурсів і природокористування Украӥни, м. Київ, Украӥна

${ }^{2}$ Київський національний університет імені Тараса Шевченка, м. Київ, Украйна

У статті наведені результати досліджень протианемічної дї Феруму (IV) у формі клатрохелатного комплексу в організмі поросят. Дослідження проведено на новонароджених поросятах-аналогах, яких розподілили у три групи - контрольну та дві дос- 
лідні. Поросят утримували зі свиноматками на підсосі. 3 метою профілактики ферумдефіцитної анемії поросятам контрольної групи одноразово внутрішньом'язово ін'єкували по 2 мл традиційного ферумовмісного препарату. У такому ж об' ємі поросятам дослідних груп внутрішньом'язово вводили: поросятам II дослідної групи - клатрохелат Феруму (IV), розчинений у реополіглюкіні; поросятам III дослідної групи - водний розчин клатрохелату Феруму (IV). В 1 мл досліджуваних розчинів містилося 100 мг діючої речовини. Матеріалом для досліджень були зразки крові та сироватки крові поросят, а також їхня печінка та селезінка. Дослід тривав 30 діб. Встановлено, шо клатрохелат Феруму (IV), розчинений у воді для ін'єкиій та реополіглюкіні, мав вищу протианемічну активність порівняно з контролем, про щчо свідчить динаміка вірогідних змін кількості еритроцитів, вмісту гемоглобіну та величини гематокриту, вмісту Феруму у сироватиі крові та його масової частки у крові, печінці та селезінці поросят. Ефективність дії клатрохелату Феруму (IV) пояснюється повночінним забезпеченням організму поросят Ферумом та його вищою біологічною доступністю. Отже, вперше виконано комплексні клінічні дослідження щзодо вивчення протианемічної дії клатрохелату Феруму (IV) на організм поросят.

Ключові слова: ферумдефіциитна анемія, клінічні дослідження, Ферум (IV), поросята, морфологічні показники, біохімічні показники.

\section{ВстуII}

Забезпечення засобами для профілактики і діагностики хвороб та лікування тварин є обов'язковою умовою успішного ведення тваринництва і базується не лише на значних капіталовкладеннях з боку держави, а й на високому рівні вітчизняного наукового потенціалу. Тож розробка нових ефективних, порівняно 3 існуючими, лікарських засобів не втрачає актуальності.

Хоча анемія є симптомокомплексом, який супроводжує численні патологічні процеси у молодняку, що завдають значних економічних збитків, насамперед виділяють аліментарну анемію (Bonkovsky \& Herbert, 1991; Camaschella, 2013; Knight \& Dilger, 2018). Це клініко-гематологічний синдром, який $є$ наслідком дефіциту в їхньому організмі незамінних для життя Феруму, Купруму, Кобальту, Цинку, вітамінів $\mathrm{C}$ і $\mathrm{B}_{12}$, що своєю чергою спричиняє порушення синтезу гемоглобіну та зменшення кількості еритроцитів (Walter et al., 1997; Svoboda et al., 2008; Ganz, 2013; Leyshon et al., 2016; Wang et al., 2019; Shero et al., 2019).

У поросят, на противагу молодняку тварин інших видів, даний вид анемії є самостійним захворюванням disease (Killip \& Bennett, 2008; Li et al., 2019). В організмі новонародженого поросяти міститься достатня кількість Феруму, який надійшов через плаценту під час внутрішньоутробного розвитку. Проте вони $є$ найнезрілішими 3 усіх сільськогосподарських тварин. Їхня маса тіла не досягає 1 \% маси тіла свиноматки, а інтенсивний ріст значно випереджає формування кровотворних органів та досконалість їх функціональної діяльності. 3 молозивом чи молоком свиноматки надходить 1 мг за добової потреби 7-10 мг (21 мг на 1 кг приросту маси тіла). До 3-тижневого віку поросята потребують вже від 114 до 200 мг Феруму, а 3 молоком вони одержують лише 23-24 мг (Levchenko, 2005). Результатом вищеописаного $\epsilon$ те, що гемоцитопоез відстає від потреб організму.

За інтенсивного ведення свинарства профілактика цієї хвороби є особливо необхідною (Sjaastad et al., 1996; Batrakov et al., 2005; Kim et al., 2018). Встановлено, що після лікування тварин з цією патологією організм, який перехворів, не здатний реалізувати власну потенційну продуктивність, а м'ясо втрачає поживні якості та має обмеження щодо реалізації. У таких тварин спостерігається блідість слизових обо- лонок, зменшення маси тіла та зниження імунітету, а це своєю чергою призводить до інфекційної патології та навіть загибелі, яка може досягати 60-70 \% (Egeli et al., 1998; Klem et al., 2010; Cooper et al., 2014).

У сучасній ветеринарній медицині для лікування тварин за ферумодефіцитної анемії та її профілактики застосовують препарати Феруму (II) або Феруму (III): пероральне введення солей Феруму (Maes et al., 2011; Svoboda et al., 2015) та парентеральне введення ферумодекстранових препаратів (Meier et al., 2011; РeñaRosas et al., 2015; Pillay et al., 2018). Їхнім недоліком $€$ низький відсоток всмоктування, що не забезпечує необхідного фармакологічного ефекту (Ma et al., 2017). Водночас вартість ферумодекстранових препаратів є досить високою.

Отже, нині на фармацевтичному ринку ветеринарних препаратів стоїть важливе завдання: у достатній мірі забезпечити його ефективними вітчизняними антианемічними засобами та мінімізувати залежність країни від закордонного виробника (Kalynovska, 2014; Derkach, 2017; Derkach et al., 2018). Науковці своєю чергою повинні працювати над розробленням таких ветеринарних препаратів, які б не мали недоліків, не володіли токсичною дією, а впливаючи на різні ланки патогенезу, забезпечували ефективну і недорогу профілактику ферумодефіцитної анемії поросят (Diel et al., 2018; Dos Santos Vieira et al., 2018).

Нами раніше повідомлялося про результати доклінічних досліжень нової органічної сполуки Феруму клатрохелату Феруму в рідкісній валентності IV, синтез якої вперше описаний Tomyn et al., (2017) (Dukhnitsky et al., 2018; 2019; 2020). Дана речовина може бути запропонована у складі ефективного протианемічного засобу для поросят.

Метою нашої роботи було оцінити ефективність застосування клатрохелату Феруму (IV) 3 метою профілактики ферумодефіцитної анемії поросят і визначити його вплив на динаміку їхньої маси тіла, вміст гемоглобіну та морфологічні показники крові, біохімічні показники сироватки крові, масові частки Феруму у крові, печінці та селезінці.

\section{Матеріал та методи дослідження}

Для виконання поставленої мети на свинокомплексі (Кагарлицький район Київської області) було відібрано 30 новонароджених поросят (гібриди порід ландрас та велика біла) у період їхнього утримання 
під свиноматками. Тварин розподілили на 3 групи (по 10 поросят у кожній) за принципом аналогів (вік та маса тіла), яких відповідно утримували в однакових умовах.

На другу добу життя для профілактики ферумодефіцитної анемії поросятам I контрольної групи вводили традиційний ферумодекстрановий препарат у дозі 2 мл для тварини. У такому ж об'ємі внутрішньом'язово вводили: поросятам II дослідної групи клатрохелат Феруму (IV), розчинений у реополіглюкіні; поросятам III дослідної групи - водний розчин клатрохелату Феруму (IV). В 1 мл розчиняли 100 мг діючої речовини.

Досліджуваний нами металокомплекс Феруму у формі клатрохелату та з рідкісною валентністю IV це макробіциклічна координаційна сполука, у якій іон металу "упакований” у нанокапсулу, яка перешкоджає взаємодії з переважною більшістю реагентів, зокрема, біолігандами, а також екранує метал від інших факторів навколишнього середовища. Вперше про синтез унікальних клатрохелатних сполук Феруму (IV), які самочинно утворюються у водних розчинах за наявності Оксигену повітря, було повідомлено Tomyn et al. (2017). Ми провели ряд доклінічних досліджень їхньої гострої та хронічної токсичності, кумулятивних властивостей тощо (Dukhnitsky et al., 2018; 2019; 2020).

Розчинник реополіглюкін є плазмозамінним колоїдним розчином декстрану (полімеру глюкози), фармакологічна дія якого проявляється поліпшенням реологічних властивостей крові, зниженням іiі в'язкості, відновленням мікроциркуляторного кровотоку, запобіганням та усуненням агрегації формених елементів, нормалізацією артеріального і венозного кровообігу. Період напіввиведення становить 6 годин. Виводиться в основному нирками: за перші 6 годин близько $60 \%$, за 24 години - 70 \%. Решта надходить у ретикулоендотеліальну систему і печінку, де поступово розщеплюється альфа-глюкозидазою до глюкози, проте не $\epsilon$ джерелом вуглеводного живлення. До того ж реополіглюкін містить Натрію хлорид, який після резорбції бере участь в обміні речовин та регуляції метаболізму води.

Протягом 30 діб за поросятами вели спостереження, методом зважування на 7, 14 та 30 добу після народження визначали динаміку змін маси тіла поросят контрольної та дослідної груп; для досліджень умісту гемоглобіну та морфологічних показників крові, біохімічних показників сироватки крові відбирали зразки крові на 7, 14, та 30 добу життя; на 30 добу відбирали проби крові, печінки та селезінки поросят для визначення у них масової частки Феруму.

\section{Результати та їх обговорення}

Відомо, що хелатні комплекси мікроелементів мають низку переваг над іншими препаратами відповідних груп, оскільки складаються 3 іонів металів та лігандів, володіють високою біологічною активністю, а їхня засвоюваність становить 95-100\%. За рахунок поступового розриву хелатних зв'язків препарати проявляють пролонговану дію. Після відщеплення мікроелементів деякі ліганди здатні ефективно використовуватися організмом. Все це дає можливість зменшувати дози мікроелементів, що є дуже важливим за застосування важких металів як діючих речовин лікарських засобів, а також вирішувати низку проблем (економічні, екологічні, біологічні тощо). Результати проведених нами досліджень підтверджують ефективність препаратів на основі клатрохелату Феруму (IV).

Зміна маси тіла тварин порівняно 3 контролем, $€$ дуже важливим показником, порушення якого свідчить про ступінь ураження організму. Зміни маси тіла особливо важливі для молодих тварин; зі збільшенням віку приріст маси відбувається значно повільніше. Нами встановлено, що динаміка змін маси тіла поросят контрольної та дослідних груп відрізняється протягом періоду дослідження, але на 30 добу експерименту показник маси тіла поросят I контрольної та III дослідної були однаковими, а показник маси тіла поросят II дослідної групи - найвищим (табл. 1).

\section{Таблиця 1}

Маса тіла поросят за впливу препаратів Феруму у валентностях III та IV, г (M \pm m, n = 10)

\begin{tabular}{llll}
\hline \multicolumn{1}{c}{ Час зважування } & \multicolumn{3}{c}{ Група поросят } \\
\cline { 2 - 4 } & \multicolumn{1}{c}{ І контрольна } & II дослідна & III дослідна \\
\hline До застосування препаратів & $1795,0 \pm 30,95$ & $1788,0 \pm 25,60$ & $1779,0 \pm 60,41$ \\
На 7 добу & $2950,0 \pm 38,64$ & $3526,4 \pm 66,71^{* * *}$ & $3680,0 \pm 67,36^{* * *}$ \\
На 14 добу & $3627,0 \pm 53,36$ & $3920,0 \pm 142,63^{* *}$ & $3892,0 \pm 33,36^{* * *}$ \\
На 30 добу & $6500,0 \pm 164,24$ & $6683,2 \pm 47,53$ & $6500,0 \pm 47,14$ \\
\hline
\end{tabular}

Примітка: ступінь вірогідності - ** - $\mathrm{P}<0,01, * * *-\mathrm{P}<0,001$

Результати досліджень (табл. 1) засвідчують, що маса тіла поросят II та III дослідних груп на 7 добу після застосування препаратів була більшою від показника в контролі на 20 та 25 \% відповідно; на 14 добу - на 8 та $7 \%$ відповідно, а через 30 діб - маса тіла поросят III дослідної групи не відрізнялася від маси тіла поросят контрольної групи, а маса тіла поросят II дослідної групи була більшою від показника в контролі на $3 \%$ відповідно.
Система крові є однією 3 найбільш мобільних та швидко реагує на зміни гомеостазу організму, що особливо важливо для новонароджених поросят за “фізіологічного” дефіциту Феруму у перші доби життя.

Морфологічні показники крові поросят дослідних груп порівнювали з контролем, аналізували динаміку змін кількості еритроцитів, умісту гемоглобіну та показника гематокриту крові (табл. 2). 
Таблиця 2

Уміст гемоглобіну та морфологічні показники крові поросят за впливу препаратів Феруму у валентностях III та $\mathrm{IV}(\mathrm{M} \pm \mathrm{m}, \mathrm{n}=10)$

\begin{tabular}{|c|c|c|c|}
\hline Показники & I контрольна & II дослідна & III дослідна \\
\hline \multicolumn{4}{|c|}{14 доба } \\
\hline Еритроцити RBC, T/л & $4,0 \pm 0,05$ & $6,7 \pm 0,10 * * *$ & $6,6 \pm 0,03 * * *$ \\
\hline Середній об'єм еритроцитів MCV, мкм³ & $62,9 \pm 0,31$ & $67,1 \pm 1,03 * *$ & $64,2 \pm 0,34$ \\
\hline Ширина розподілу еритроцитів, \% & $14,7 \pm 0,08$ & $15,3 \pm 0,19^{*}$ & $15,2 \pm 0,08 * * *$ \\
\hline Гемоглобін HGB, г/л & $79,6 \pm 0,96$ & $102,0 \pm 6,00^{* *}$ & $123,5 \pm 0,58^{* * *}$ \\
\hline Середній вміст гемоглобіну в одному еритроциті МСН, пкг & $18,7 \pm 0,08$ & $19,2 \pm 0,48$ & $18,4 \pm 0,09 *$ \\
\hline Концентрація гемоглобіну в еритроцитах МСНС, г/дл & $29,5 \pm 0,13$ & $28,7 \pm 0,11^{* * *}$ & $28,6 \pm 0,21 *$ \\
\hline Гематокрит НСТ, \% & $37,5 \pm 0,97$ & $42,8 \pm 1,38 * * *$ & $41,5 \pm 0,53 * * *$ \\
\hline Лейкоцити WBC, тис./мкл & $8,0 \pm 0,38$ & $10,0 \pm 0,48 * *$ & $12,6 \pm 0,50 * * *$ \\
\hline Тромбоцити PLT, тис./ мм ${ }^{3}$ & $419,0 \pm 4,27$ & $427,9 \pm 10,25$ & $464,2 \pm 4,54 * * *$ \\
\hline Середній об'єм тромбоцитів MPV мкм³ & $9,0 \pm 0,47$ & $9,1 \pm 0,17$ & $8,8 \pm 0,13$ \\
\hline ШOE & $4,0 \pm 0,15$ & $3,3 \pm 0,15^{* *}$ & $3,0 \pm 0,21 * *$ \\
\hline \multicolumn{4}{|c|}{30 доба } \\
\hline Еритроцити RBC, T/л & $6,9 \pm 0,05$ & $7,54 \pm 0,10^{* * *}$ & $6,9 \pm 0,07$ \\
\hline Середній об'єм еритроцитів MCV, мкм ${ }^{3}$ & $58,6 \pm 0,73$ & $62,2 \pm 0,82 * *$ & $62,0 \pm 0,81$ \\
\hline Ширина розподілу еритроцитів, \% & $13,3 \pm 0,14$ & $13,6 \pm 0,05^{*}$ & $13,2 \pm 0,03$ \\
\hline Гемоглобін HGB, г/л & $121,6 \pm 0,73$ & $132,0 \pm 0,50 * * *$ & $127,0 \pm 0,50 * * *$ \\
\hline Середній вміст гемоглобіну в одному еритроциті МСН, пкг & $17,2 \pm 0,08$ & $17,9 \pm 0,13^{* * *}$ & $17,6 \pm 0,21 *$ \\
\hline Концентрація гемоглобіну в еритроцитах МСНС, г/дл & $29,3 \pm 0,22$ & $29,7 \pm 0,25$ & $29,1 \pm 0,09$ \\
\hline Гематокрит НСТ, \% & $42,0 \pm 0,42$ & $45,9 \pm 0,38^{* * *}$ & $42,7 \pm 0,18$ \\
\hline Лейкоцити WBC, тис./мкл & $10,6 \pm 0,98$ & $11,6 \pm 0,46$ & $13,3 \pm 0,71 *$ \\
\hline Тромбоцити PLT, тис. / мм ${ }^{3}$ & $458,4 \pm 1,97$ & $441,4 \pm 10,85$ & $468,7 \pm 6,05^{*}$ \\
\hline Середній об'єм тромбоцитів MPV мкм³ & $9,8 \pm 0,43$ & $9,8 \pm 0,11$ & $10,2 \pm 0,34$ \\
\hline ШOE & $4,0 \pm 0,14$ & $3,0 \pm 0,15^{* * *}$ & $3,5 \pm 0,16^{*}$ \\
\hline
\end{tabular}

3 даних, наведених у таблиці 2, випливає, що на 14 добу після застосування препаратів Феруму (IV) у крові поросят II дослідної групи кількість еритроцитів, уміст гемоглобіну та показник гематокриту зростали у $1,7,1,3,1,1$ (Р < 0,01, Р < 0,001) разу відповідно, а у крові поросят III дослідної групи у 1,7, 1,6, 1,1 ( $<0,001)$ разу відповідно порівняно 3 контролем. Період досліджень (14 діб) характеризується тим, що організмом поросят уже використано резервні запаси Феруму (до 7 доби), а надходження його 3 молоком матері задовольняє потребу організму поросят лише на 10-15\%. Тому застосування ферумовмісних препаратів на основі клатрохелату Феруму (IV) відвернуло розвиток еритроцитопенії та гіпогемоглобінемії, зумовлених пригніченням гемоцитопоетичної функції кісткового мозку за дефіциту Феруму.

На 30 добу у крові поросят II дослідної групи кількість еритроцитів, уміст гемоглобіну та показник гематокриту були більшими від показників тварин контрольної групи, а у крові поросят III дослідної групи майже не змінювалися порівняно з контролем.

Динаміка вірогідних змін $(\mathrm{P}<0,05, \mathrm{P}<0,01$, $\mathrm{P}<0,00)$ показників середнього об'єму еритроцитів $\mathrm{MCV}$, ширини розподілу еритроцитів, середнього вмісту гемоглобіну в одному еритроциті МСН та концентрації гемоглобіну в еритроцитах МСНС доповнюють вищеописані зміни та засвідчують високий профілактичний протианемічний вплив клатрохелату
Феруму (IV), розчиненого в таких розчинниках, як вода для ін'єкцій та реополіглюкін.

На 14 добу після застосування препаратів Феруму (IV) у крові поросят II дослідної групи кількість лейкоцитів збільшувалася в 1,3 (P < 0,01,) разу, а у крові поросят III дослідної групи - у 1,6 (P < 0,001) разу, порівняно 3 контролем. На 30 добу цей показник майже не відрізнявся від контролю.

Також не зазнавали суттєвих змін уподовж 30 діб показники кількості та середнього об'єму тромбоцитів у поросят дослідних груп.

Показник ШОЕ у поросят обох дослідних груп був меншим у 1,2-1,3 разу від контролю протягом періоду експерименту.

За впливу препаратів клатрохелату Феруму (IV) суттєвих змін зазнавала лейкограма крові поросят (табл. 3).

3 даних, наведених у таблиці 3, випливає, що на 14 та 30 доби динаміка показників кількості паличкоядерних та сегментоядених нейтрофілів у крові поросят дослідних груп відрізнялася від контролю. Зокрема, кількість паличкоядерних нейтрофілів була меншою у крові поросят II дослідної групи у 2,2 та 2,6 ( $>0,001)$ разу відповідно, а у крові поросят III дослідної групи - у 2,6 та 3,3 (P < 0,01, $\mathrm{P}<0,001)$ разу відповідно порівняно 3 контролем. Кількість сегментоядерних нейтрофілів у крові поросят дослідних груп була, навпаки, дещо більшою, ніж в контролі. 
Таблиця 3

Лейкограма крові поросят за впливу препаратів Феруму у валентностях III та IV, \% (M \pm m, n = 10)

\begin{tabular}{lccc}
\hline \multicolumn{1}{c}{ Показники } & I контрольна & II дослідна & III дослідна \\
\hline Базофіли & 14 доба & & - \\
Еозинофіли & - & - & $4,5 \pm 0,40$ \\
Нейтрофіли паличкоядерні & $4,0 \pm 0,33$ & $5,0 \pm 0,82$ & $4,0 \pm 0,21^{* *}$ \\
Нейтрофіли сегментоядерні & $5,1 \pm 0,23$ & $2,3 \pm 0,25 * * *$ & $49,2 \pm 0,29 * * *$ \\
Лімфоцити & $46,0 \pm 0,47$ & $48,7 \pm 0,25$ & $43,1 \pm 0,53 *$ \\
Моноцити & $40,0 \pm 1,35$ & $40,1 \pm 1,30$ & $2,0 \pm 0,21^{* *}$ \\
\hline & $6,0 \pm 0,26$ & $3,0 \pm 0,49 * *$ & - \\
\hline Базофіли & 30 доба & & $5,5 \pm 0,41$ \\
Еозинофіли & - & $4,7 \pm 0,30$ & $1,2 \pm 0,14^{* * *}$ \\
Нейтрофіли паличкоядерні & $5,1 \pm 0,98$ & $1,5 \pm 0,15^{* * *}$ & $55,1 \pm 0,32$ \\
Нейтрофіли сегментоядерні & $4,0 \pm 0,22$ & $61,0 \pm 0,82^{* *}$ & $37,4 \pm 0,48^{* * *}$ \\
Лімфоцити & $55,9 \pm 1,26$ & $29,0 \pm 0,26 * * *$ & $2,0 \pm 0,32^{* * *}$ \\
Моноцити & $32,1 \pm 0,47$ & $5,0 \pm 0,26$ &
\end{tabular}

Кількість моноцитів у крові поросят II та III дослідних груп на 14 добу була меншою у 2,0 та 3,0 $(\mathrm{P}<0,01)$ разу відповідно порівняно з контролем, а на 30 добу у крові поросят II дослідної групи не відрізнялася від контролю, а у крові поросят III дослідної групи була меншою.

Кількості лімфоцитів та еозинофілів у крові поросят II та III дослідних груп майже не відрізнялася від показників у поросят контрольної групи.

У крові поросят усіх груп не встановлено промієлоцитів, мієлоцитів, метамієлоцитів, базофілів та плазматичних клітин упродовж періоду дослідження.
В основі біологічної дії хімічних факторів лежить порушення низки біохімічних процесів. Основне значення у цьому мають структурно-метаболічні комплекси, які пов'язані зі синтезом білка, біоенергетикою метаболізму хімічних сполук і процесами катаболізму. Біохімічні дослідження включають аналізи показників, які відображають функціональний стан окремих органів.

Динаміка змін умісту Феруму в сироватці крові поросят контрольної та дослідних груп наведена у таблиці 4.

\section{Таблиця 4}

Уміст Феруму у сироватці крові поросят за впливу препаратів Феруму у валентностях III та IV, ммоль/л (M \pm m, $\mathrm{n}=10)$

\begin{tabular}{lccc}
\hline \multirow{2}{*}{ Період дослідження, доба } & \multicolumn{3}{c}{ Група поросят } \\
\cline { 2 - 4 } & I контрольна & II дослідна & III дослідна \\
\hline На 7 добу & $24,1 \pm 2,58$ & $40,5 \pm 2,32^{* * *}$ & $37,3 \pm 2,95^{* *}$ \\
На 14 добу & $20,8 \pm 1,01$ & $48,5 \pm 3,51^{* * *}$ & $29,4 \pm 0,76^{* * *}$ \\
На 30 добу & $14,7 \pm 0,912$ & $22,0 \pm 0,77^{* * *}$ & $17,6 \pm 1,22$ \\
\hline
\end{tabular}

Примітка: ступінь вірогідності: ** - $\mathrm{P}<0,01, * * *-\mathrm{P}<0,001$

3 даних, наведених у таблиці 4, випливає, що на 7, 14 та 30 доби уміст Феруму в сироватці крові поросят II дослідної групи був вищим у 1,7, 2,3, 1,5 (P < 0,001) разу відповідно, а у сироватці крові поросят III дослідної групи - у 1,5, 1,4, 1,2 (P < 0,01, $\mathrm{P}<0,001)$ разу відповідно порівняно з контролем.

Високий уміст Феруму в сироватці крові поросят II групи засвідчує, що клатрохелат Феруму (IV), розчинений у реополіглюкіні, створює депо Феруму в сироватці крові на тривалий час.

Важливу інформацію про метаболізм в організмі поросят за впливу Феруму у валентностях III та IV було отримано за вивчення упродовж 30 діб динаміки змін інших біохімічних показників сироватки крові (табл. 5).

Наведені у табл. 5 дані засвідчують, що на 7 добу вірогідно зміни деяких показників були лише у сиро- ватці крові поросят II дослідної групи, яким застосовували клатрохелат Феруму (IV), розчинений у реополіглюкіні. Зокрема збільшувався уміст протеїну загального, $\alpha_{1-}, \beta$ - та $\gamma$-глобулінів.

Через 14 діб вірогідне збільшення показників протеїну загального, $\alpha_{2-}, \beta$ - та $\gamma$-глобулінів було встановлено у сироватці крові поросят обох дослідних груп. Уміст альбумінів у сироватці крові II дослідної групи вірогідно підвищувався на $14 \%$, а в сироватці крові поросят III дослідної групи - знижувався на 5 \%.

Через 30 діб у сироватці крові поросят обох дослідних груп вірогідно вищим від контролю був уміст протеїну загального, $\alpha_{2-}$, та $\beta$-глобулінів. Уміст $\gamma$ глобулінів у сироватці крові поросят обох дослідних груп був меншим, ніж у контролі. 


\section{Таблиця 5}

Деякі біохімічні показники сироватки крові поросят за впливу препаратів Феруму у валентностях III та IV $(\mathrm{M} \pm \mathrm{m}, \mathrm{n}=10)$

\begin{tabular}{|c|c|c|c|}
\hline \multirow[t]{2}{*}{ Показники } & I контрольна & II дослідна & III дослідна \\
\hline & \multicolumn{3}{|c|}{7 доба } \\
\hline Протеїн загальний, г/л & $45,8 \pm 0,29$ & $47,1 \pm 0,49^{*}$ & $44,6 \pm 1,61$ \\
\hline Альбуміни, \% & $53,2 \pm 0,81$ & $53,5 \pm 0,68$ & $54,4 \pm 0,21$ \\
\hline$\alpha_{1}$-глобуліни, \% & $2,4 \pm 0,03$ & $3,0 \pm 0,09 * * *$ & $2,6 \pm 0,08$ \\
\hline$\alpha_{2}$-глобуліни, \% & $10,7 \pm 0,59$ & $9,0 \pm 0,68$ & $11,2 \pm 0,73$ \\
\hline$\beta$-глобуліни, \% & $16,8 \pm 0,34$ & $12,8 \pm 0,65 * * *$ & $16,3 \pm 0,05$ \\
\hline$\gamma$-глобуліни, \% & $17,0 \pm 1,15$ & $21,3 \pm 0,33 * *$ & $15,1 \pm 0,52$ \\
\hline А/Г коефіцієнт & $1,1 \pm 0,04$ & $1,2 \pm 0,03$ & $1,2 \pm 0,01$ \\
\hline Глюкоза, ммоль/л & $7,5 \pm 0,02$ & $7,4 \pm 0,35$ & $6,8 \pm 0,30$ \\
\hline Фосфор неорганічний, ммоль/л & $3,8 \pm 0,06$ & $3,9 \pm 0,11$ & $3,8 \pm 0,15$ \\
\hline Кальцій загальний, ммоль/л & $2,8 \pm 0,06$ & $2,8 \pm 0,02$ & $3,1 \pm 0,04 * * *$ \\
\hline \multicolumn{4}{|c|}{14 доба } \\
\hline Протеїн загальний, г/л & $44,6 \pm 1,16$ & $50,5 \pm 0,60 * * *$ & $52,7 \pm 0,78 * * *$ \\
\hline Альбуміни, \% & $54,7 \pm 0,48$ & $62,4 \pm 0,73 * * *$ & $52,1 \pm 0,26^{* * *}$ \\
\hline 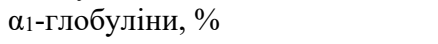 & $2,2 \pm 0,05$ & $2,1 \pm 0,11$ & $1,1 \pm 0,02 *$ \\
\hline$\alpha_{2}$-глобуліни, \% & $10,2 \pm 0,34$ & $12,4 \pm 0,39 * * *$ & $13,2 \pm 0,02 * * *$ \\
\hline$\beta$-глобуліни, \% & $14,0 \pm 0,47$ & $15,3 \pm 0,16^{*}$ & $17,2 \pm 0,05 * * *$ \\
\hline$\gamma$-глобуліни, \% & $16,5 \pm 0,41$ & $17,1 \pm 1,25$ & $15,5 \pm 0,10^{*}$ \\
\hline A/Г коефіцієнт & $1,3 \pm 0,04$ & $1,6 \pm 0,06 * * *$ & $1,1 \pm 0,01 * * *$ \\
\hline Глюкоза, ммоль/л & $6,8 \pm 0,19$ & $7,0 \pm 0,22$ & $6,3 \pm 0,06^{*}$ \\
\hline Фосфор неорганічний, ммоль/л & $3,4 \pm 0,12$ & $2,7 \pm 0,07 * * *$ & $2,6 \pm 0,03 * * *$ \\
\hline Кальцій загальний, ммоль/л & $2,5 \pm 0,11$ & $2,7 \pm 0,04$ & $2,9 \pm 0,08 * *$ \\
\hline \multicolumn{4}{|c|}{30 доба } \\
\hline Протеїн загальний, г/л & $47,1 \pm 0,52$ & $48,7 \pm 0,46^{*}$ & $50,4 \pm 0,26 * * *$ \\
\hline Альбуміни, \% & $58,1 \pm 1,02$ & $57,4 \pm 0,91$ & $57,9 \pm 0,21$ \\
\hline 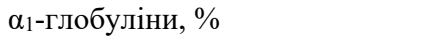 & $1,9 \pm 0,09$ & $2,9 \pm 0,08 * * *$ & $1,7 \pm 0,16^{* * *}$ \\
\hline$\alpha_{2}$-глобуліни, \% & $9,9 \pm 0,28$ & $11,3 \pm 0,52 *$ & $13,2 \pm 0,02 *$ \\
\hline$\beta$-глобуліни, \% & $12,2 \pm 0,42$ & $15,6 \pm 0,24 * * *$ & $17,2 \pm 0,05 * * *$ \\
\hline ү-глобуліни, \% & $16,6 \pm 0,42$ & $12,8 \pm 0,72 * * *$ & $15,5 \pm 0,10 * * *$ \\
\hline А/Г коефіцієнт & $1,5 \pm 0,06$ & $1,4 \pm 0,05$ & $1,1 \pm 0,01$ \\
\hline Глюкоза, ммоль/л & $6,4 \pm 0,10$ & $6,1 \pm 0,20$ & $5,4 \pm 0,20 * * *$ \\
\hline Фосфор неорганічний, ммоль/л & $2,6 \pm 0,14$ & $3,0 \pm 0,10$ & $3,3 \pm 0,01 * *$ \\
\hline Кальцій загальний, ммоль/л & $2,5 \pm 0,14$ & $2,6 \pm 0,05$ & $2,7 \pm 0,03$ \\
\hline
\end{tabular}

Примітка: ступінь вірогідності: * $-\mathrm{P}<0,05, * *-\mathrm{P}<0,01, * * *-\mathrm{P}<0,001$

Показники вмісту глюкози, кальцію загального та фосфору неорганічного у сироватці крові поросят дослідних груп суттєво не відрізнялися від контролю впродовж усього досліду.

Дослідженнями встановлено, що уміст Феруму в крові, печінці та селезінці піддослідних поросят залежав від застосованого препарату (табл. 6).

\section{Таблиця 6}

Масова частка Феруму у крові, печінці та селезінці поросят за впливу препаратів Феруму (III) і (IV), мг/кг $(\mathrm{M} \pm \mathrm{m}, \mathrm{n}=5)$

\begin{tabular}{lcc}
\hline \multirow{2}{*}{ Показник } & \multicolumn{2}{c}{ Група поросят } \\
\cline { 2 - 3 } & І контрольна & II дослідна \\
\hline Кров & $212,6 \pm 3,22$ & $266,6 \pm 4,48 * * *$ \\
Печінка & $94,8 \pm 2,22$ & $106,8 \pm 1,77 * *$ \\
Селезінка & $92,4 \pm 0,82$ & $101,7 \pm 0,95 * * *$ \\
\hline Примітка: ступінь вірогідності: ** $-\mathrm{P}<0,01, * * *-\mathrm{P}<0,001$
\end{tabular}

Так, його уміст на 30 добу був більшим у крові, печінці та селезінці поросят II дослідної групи (застосовували розчин клатрохелату Феруму (IV) на реополіглюкіні) на 25,13 та 10 \% відповідно, ніж за застосу- вання ферумовмісного декстранового препарату (І контрольна група).

Отже, за показниками маси тіла, морфологічними та біохімічними показниками крові та сироватки крові поросят препарати клатрохелату Феруму (IV) були ефективніші, ніж традиційні ферумодекстранові.

\section{Висновки}

Збільшення маси тіла поросят II та III дослідних груп порівняно з контролем через 7 діб після застосування препаратів клатрохелату Феруму (IV) на 576,4 та 730,0 г; через 14 діб - на 293,0 та 265 г відповідно засвідчує про активацію процесів синтезу в їх організмі. Під впливом препаратів клатрохелату Феруму (IV) стимулювався гемоцитопоез у поросят дослідних груп, на що вказує вірогідно більший уміст гемоглобіну та кількість ерироцитів у їхній крові, величина гематокриту, порівняно з показниками поросят контрольної групи. За застосування препаратів клатрохелату Феруму (IV) поросятам II та III дослідних груп, уміст Феруму у їх сироватці крові був більшим, ніж у контролі в 1,5-2,3 та 1,2-1,5 разу відповідно. Високий уміст Феруму в сироватці крові поросят II 
дослідної групи упродовж 30 діб засвідчує про здатність клатрохелату Феруму (IV), розчиненого у реополіглюкіні, створювати депо Феруму на тривалий час. Висока біодоступність клатрохелату Феруму (IV), розчиненого у реополіглюкіні, порівняно 3 декстриновим препаратом, підтверджується більшим умістом Феруму в крові, печінці та селезінці поросят дослідних груп на 25,13 та $10 \%$.

\section{References}

Batrakov, A., Travkin, O., \& Jakovleva, E. (2005). Profilaktika alimentarnoj anemii u porosjat [Prevention of malignant anemia of piglets]. Veterinarija, 12, 44-45 (in Russian).

Bhattarai, S., Framstad, T., \& Nielsen, J. P. (2019). Iron treatment of pregnant sows in a Danish herd without iron deficiency anemia did not improve sow and piglet hematology or stillbirth rate. Acta Veterinaria Scandinavica, 61(1), 60. doi: 10.1186/s13028-0190497-6.

Bhattarai, S., Framstad, T., \& Nielsen, J. P. (2019). Association between sow and piglet blood hemoglobin concentrations and stillbirth risk. Acta Veterinaria Scandinavica, 61(1), 61. doi: 10.1186/s13028-0190496-7.

Bonkovsky, S., \& Herbert, L. (1991). Iron and the liver. The American journal of the medical sciences, 301(1), 32-43. doi: 10.1097/00000441-199101000-00006.

Camaschella, C. (2013). Iron and hepcidin: a story of recycling and balance. Hematology. American Society of Hematology. Education Program, 2013, 1-8. doi: 10.1182/asheducation-2013.1.1.

Chen, X., Zhang, X., Zhao, J., Tang, X., Wang, F., \& Du, H. (2019). Split iron supplementation is beneficial for newborn piglets. Biomedicine \& Pharmacotherapy, 120, 109479. doi: 10.1016/j.biopha.2019.109479.

Churio, O., Durán, E., Guzmán-Pino, S. A., \& Valenzuela, C. (2018). Use encapsulation technology to improve the efficiency of an iron oral supplement to prevent anemia in suckling pigs. Animals, 9(1), 1. doi: 10.3390/ani9010001.

Cooper, C. A., Moraes, L. E., Murray, J. D., \& Owens, S. D. (2014). Hematologic and biochemical reference intervals for specific pathogen free 6-week-old Hampshire-Yorkshire crossbred pigs. Journal of Animal Science and Biotechnology, 5(1), 5. doi: 10.1186/2049-1891-5-5.

Derkach, I. (2017). Suchasni tendentsii na vitchyznianomu rynku ferumvmisnykh preparativ dlia tvaryn [Modern trends of the Ukrainian market of ironcontaining products for animals]. Naukovyi visnyk Lvivskoho natsionalnoho universytetu veterynarnoi medytsyny ta biotekhnolohii imeni S. Z. Hzhytskoho, 19(78), 23-25. doi: 10.15421/nvlvet7805 (in Ukrainian).

Derkach, I., Derkach, S., \& Sotnichenko, I. (2018). Ferum u skladi kormovykh dobavok, hotovykh kormiv ta premiksiv na farmatsevtychnomu rynku v Ukraini [Iron in the content of feed additives, prepared feeds and premixes on the pharmaceutical market in
Ukraine]. Naukovyi visnyk Lvivskoho natsionalnoho universytetu veterynarnoi medytsyny ta biotekhnolohii imeni S. Z. Hzhytskoho, 20(83), 290-294. doi: $10.15421 /$ nvlvet8358 (in Ukrainian).

Diel, J., Bertoldi, A., \& Pizzol, T. (2018). Iron salts and vitamins: use, purchase and sources of obtainment among children in Brazil. Cad Saude Publica, 6, 34(9). doi: 10.1590/0102-311X00133317.

Dos Santos Vieira, D. A., Hermes Sales, C., Galvão Cesar, C. L., Marchioni, D. M., \& Fisberg, R. M. (2018). Influence of haem, non-haem, and total iron intake on metabolic syndrome and its components: a population-based study. Nutrients, 10(3), 314. doi: 10.3390/nu10030314.

Dukhnitsky, V. B., Derkach, I. M., Plutenko, M. O., Fritsky, I. O., \& Derkach, S. S. (2018). Vyznachennia parametriv hostroi toksychnosti ferumu (IV) na bilykh myshakh [Determination of the accumulative toxicity parameters of iron (IV) on white mice]. Ukrainian Journal of Ecology, 8(2), 308-312. doi: 10.15421/2018_343 (in Ukrainian).

Dukhnitsky, V. B., Derkach, I. M., Derkach, S. S., Plutenko, M. O. \& Fritsky, I. O. (2019). Influence of iron (IV) clathrochelate complex on quail blood parameters and weight characteristics. Ukrainian Journal of Ecology, 9(3), 126-131. doi: 10.15421/2019_719.

Dukhnitsky, V. B., Kalachniuk L.H.H., Derkach, I. M., Derkach, S. S., Plutenko, M. O. \& Fritsky, I. O. (2020). Iron (IV) hexahydrazide clathrochelate complexes: the chronic toxicity study. Ukrainian Journal of Ecology, 9(3), 18-23. doi: 10.15421/2020_3.

Ganz, T. (2013). Systemic iron homeostasis. Physiological Reviews, 93(4), 1721-1741. doi: 10.1152/physrev.00008.

Ganz, T., \& Nemeth, E. (2006). Iron imports. IV. Hepcidin and regulation of body iron metabolism. American Journal of Physiology. Gastrointestinal and liver physiology, 290(2), G199-G203. doi: 10.1152/ajpgi.00412.2005.

Ganz, T., \& Nemeth, E. (2012). Hepcidin and iron homeostasis. Biochimica et Biophysica Acta, 1823(9), 1434-1443. doi: 10.1016/j.bbamcr.2012.01.014.

Grabovskyi, S. S. (2014). Effect of natural immunomodulators influence on cellular immunity indices and cortisol level in rat's blood at preslaughter stress. Studia Biologica, 8(1), 93-102.

Egeli, A. K., Framstad, T., \& Morberg, H. (1998). Clinical biochemistry, haematology and body weight in piglets. Acta veterinaria Scandinavica, 39(3), 381-393.

Kalynovska, L. (2014). Zareiestrovani v Ukraini preparaty dlia profilaktyky i likuvannia tvaryn pry anemii [Medicines which are registered in Ukraine for the prevention and treatment of animals with anemia]. Naukovo-tekhnichnyi biuleten Instytutu biolohii tvaryn i Derzhavnoho naukovo-doslidnoho kontrolnoho instytutu veterynarnykh ta kormovykh dobavok, 15(1), 279-283 (in Ukrainian).

Khariv, I. I. (2013). Vplyv "Amprolinsylu" ta brovitakoktsydu na pokaznyky klitynnoho i humoralnoho imunitetu indykiv za eymeriozohistomonoznoyi invaziyi [Influence of amprolissil and broth tacticide on indicators of cell and humoral 
immunity of turkey cocks under the emeritushistomonous invasi-on]. Biolohiya Tvaryn, 15(4), 159-165 (in Ukrainian).

Kim, J. C., Wilcock, P., \& Bedford, M. R. (2018). Iron status of piglets and impact of phytase superdosing on iron physiology: A review. Animal Feed Science and Technology, 235, 8-14. doi: 10.1016/j.anifeedsci. 2017.11.001.

Killip, S., Bennett, M. Iron Deficiency Anemia (2008). American Family Physician, 15, 78(8), 671-678.

Klem, T. B., Bleken, E., Morberg, H., Thoresen, S. I., \& Framstad, T. (2010). Hematologic and biochemical reference intervals for Norwegian crossbreed grower pigs. Veterinary Clinical Pathology, 39(2), 221-226. doi: 10.1111/j.1939-165X.2009.00199.x.

Knez, M., Graham, R. D., Welch, R. M., \& Stangoulis, J. C. (2017). New perspectives on the regulation of iron absorption via cellular zinc concentrations in humans. Critical Reviews in Food Science and Nutrition, 57(10), 2128-2143. doi: 10.1080/10408398.2015.1050483.

Knight, L. C., \& Dilger, R. N. (2018). Longitudinal effects of iron deficiency anemia and subsequent repletion on blood parameters and the rate and composition of growth in pigs. Nutrients, 10(5), 632. doi: 10.3390/nu10050632.

Leyshon, B. J., Radlowski, E. C., Mudd, A. T., Steelman, A. J., \& Johnson, R. W. (2016). Postnatal iron deficiency alters brain development in piglets. The Journal of Nutrition, 146(7), 1420-1427. doi: 10.3945/jn.115.223636.

Levchenko, V., Zajarnuk, V., Papchenko, I., Abdullaev, Sh., Bogatko, L., Kostenko., L., Sokoluk., V., Sharandak, V., Shulga, P. (2005). Khvoroby svynei [Diseases of pigs]. Bila tserkva: Bilotserkivskyi derzhavnyi ahrarnyi universytet (in Ukrainian).

Li, R., Wang, F., Zhang, Y., Li, C., Xia, C., Chen, H., Lu, X., \& Liu, F. (2019). Comparison of hematologic and biochemical reference values in specific-pathogen-free 1-month-old Yorkshire pigs and Yorkshire-Landrace crossbred pigs. Canadian Journal of Veterinary Research, 83(4), 285-290. URL: https://www.ncbi. nlm.nih.gov/pmc/articles/PMC6753882.

Lipinski, P., Starzyński, R. R., Canonne-Hergaux, F., Tudek, B., Oliński, R., Kowalczyk, P., Dziaman, T., Thibaudeau, O., Gralak, M. A., Smuda, E., Woliński, J., Usińska, A., \& Zabielski, R. (2010). Benefits and risks of iron supplementation in anemic neonatal pigs. The American Journal of Pathology, 177(3), 12331243. doi: 10.2353/ajpath.2010.091020.

Lipiński, P., Styś, A., \& Starzyński, R. R. (2013). Molecular insights into the regulation of iron metabolism during the prenatal and early postnatal periods. Cellular and Molecular Life Sciences: CMLS, 70(1), 23-38. doi: 10.1007/s00018-012-1018-1.

Ma, W., Lu, J., Jiang, S., Cai, D., Pan, S., Jia, Y., \& Zhao, R. (2017). Maternal protein restriction depresses the duodenal expression of iron transporters and serum iron level in male weaning piglets. The British Journal of Nutrition, 117(7), 923-929. doi: $10.1017 / \mathrm{S} 0007114517000794$.

Maes, D., Steyaert, M., Vanderhaeghe, C., López
Rodríguez, A., de Jong, E., Del Pozo Sacristán, R., Vangroenweghe, F., \& Dewulf, J. (2011). Comparison of oral versus parenteral iron supplementation on the health and productivity of piglets. Veterinary Record, 19, 168-188. doi: 10.1136/vr.c7033.

Meier, T., Schropp, P., Pater, C., Leoni, A., Khov-Tran, V., \& Elford, P. (2011). Physicochemical and toxicological characterization of a new generic iron sucrose preparation. Arzneimittelforschung, 61(2), 112-119. doi: 10.1055/s-0031-1296176.

Miranda, M., \& Lawson, H. (2018). Ironing out the details: untangling dietary iron and genetic background in diabetes. Nutrients, 10(10), 1-9. doi: 10.3390/nu10101437.

Nemeth, E., \& Ganz, T. (2006). Regulation of iron metabolism by hepcidin. Annual Review of Nutrition, 26, 323-342. doi: 10.1146/annurev.nutr.26.061505. 111303.

Pillay, D., Wham, C., Moyes, S., Muru-Lanning, M., Teh R., \& Kerse N. (2018). Intakes, adequacy, and biomarker status of iron, folate, and vitamin b12 in māori and non-māori octogenarians: life and living in advanced age: a cohort study in New Zealand (LiLACS NZ). Nutrients, 14, 10(8), 1-9. doi: 10.3390/nu10081090.

Peña-Rosas, J., De-Regil, L., Gomez Malave, H., FloresUrrutia, M., \& Dowswell, T. (2015). Intermittent oral iron supplementation during pregnancy. Cochrane Database System Review, 19(10), 1-9. doi: 10.1002/14651858.

Sangkhae, V., \& Nemeth, E. (2017). Regulation of the Iron Homeostatic Hormone Hepcidin. Advances in nutrition (Bethesda, Md.), 8(1), 126-136. doi: 10.3945/an.116.013961.

Shero, N., Fiset, S., Blakley, B., Jougleux, J. L., Surette, M. E., Thabet, M., \& Rioux, F. M. (2019). Impact of maternal iron deficiency on the auditory functions in the young and adult guinea pig. Nutritional Neuroscience, 22(6), 444-452. doi: 10.1080/1028415X.2017.1408946.

Sjaastad, O. V., Framstad, T., \& Blom, A. K. (1996). Effect of iron on erythropoietin production in anaemic piglets. Acta Veterinaria Scandinavica, 37(2), 133138. URL: https://pubmed.ncbi.nlm.nih.gov/8767691.

Starzyński, R. R., Laarakkers, C. M., Tjalsma, H., Swinkels, D. W., Pieszka, M., Styś, A., Mickiewicz, M., \& Lipiński, P. (2013). Iron supplementation in suckling piglets: how to correct iron deficiency anemia without affecting plasma hepcidin levels. PloS one, 8(5), e64022. doi: 10.1371/journal.pone.0064022.

Svoboda, M., \& Drabek, J. (2005). Iron deficiency in suckling piglets: etiology, clinical aspects and diagnosis. Folia Veterinaria, 49, 104-111.

Svoboda, M, \& Pískova, K. (2018). Oral iron administration in suckling piglets - a review. Acta Vet Brno, 87, 77-83.

Szudzik, M., Starzyński, R. R., Jończy, A., Mazgaj, R., Lenartowicz, M., \& Lipiński, P. (2018). Iron supplementation in suckling piglets: an ostensibly easy therapy of neonatal iron deficiency anemia. Pharmaceuticals (Basel, Switzerland), 11(4), 128. 
doi: 10.3390/ph11040128.

Szudzik, M., Lipiński, P., Jończy, A., Mazgaj, R., Pieszka, M., Kamyczek, M., Smuda, E., \& Starzyński, R. R. (2020). Long-term effect of split iron dextran/hemoglobin supplementation on erythrocyte and iron status, growth performance, carcass parameters, and meat quality of polish large white and 990 line pigs. Biological Trace Element Research, 196(2), 472-480. doi: 10.1007/s12011-019-01950-w.

Tomyn, S., Shylin, S., Bykov, D., Ksenofontov, V., Gumienna-Kontecka, E., Bon, V., \& Fritsky, I. (2017). Indefinitely stable iron (IV) cage complexes formed in water by air oxidation. Nature Communications, $8,1-$ 8. doi: 10.1038/ncomms14099.

Wang, X., Garrick, M. D., \& Collins, J. F. (2019). Animal models of normal and disturbed iron and copper metabolism. The Journal of Nutrition, 149(12), 20852100. doi: 10.1093/jn/nxz172.

Walter, T., Olivares, M., Pizarro, F., \& Muñoz, C. (1997). Iron, anemia, and infection. Nutrition Reviews, 55(4), 111-124. doi: 10.1111/j.1753-4887.1997.tb06462.x. 